\title{
Analisis Peran Sektor Basis dan Non Basis dalam Penyerapan Tenaga Kerja di Kabupaten Gresik
}

\author{
HADINA RIZKY AMALIA \\ HERRY YULISTIYONO \\ Fakultas Ekonomi dan Bisnis Universitas Trunojoyo Madura \\ Jl. Raya Telang, Perumahan Telang Inda, Kabupaten Bangkalan, Jawa Timur \\ Email: herryyulistiyono@gmail.com
}

Diterima 25 September 2020; disetujui 30 September 2020;

\begin{abstract}
This research aims to identify base and non-base sectors and analyze the absorption of labor in the base and non-base sectors in Gresik Regency as information and consideration in economic development planning. This research is a descriptive quantitative study using secondary data of PDRB variables and labor and its components in Gresik Regency. The analytical methods used in this study are LQ analysis, shiftshare analysis, MRP analysis and labor absorption analysis. The results of the $L Q$ analysis show the processing industry sector, the mining and quarrying sectors and the electricity and gas procurement sector are the base sectors. The results of the shiftshare analysis show sectors where the average power growth is higher than overall economic growth are the agricultural sector, the provision of drinking accommodation, construction, trade, transportation and warehousing, information and communication, financial services, corporate services, education services and the healthcare sector. While the sectors whose average local competitiveness growth is higher than the competitiveness of the same sector in East Java Province are agriculture, electricity procurement, water procurement, construction, trade, information and communication, food and drink accommodation provision sector, corporate services sector, government administration, education services, health and other service sectors. The results of the MRP analysis also show that the electricity and gas procurement sector is the leading sector in terms of growth. From the analysis of labor elasticity, it is known that the average sector with the highest labor elasticity value in 2011-2015 is the base sector, namely the mining sector and the electricity and gas procurement sector and in 2016-2017 is the non-base sector, namely the transportation sector and financial institutions.
\end{abstract}

Keywords: Base Sector, MRP Analysis, Labour Absorption

\section{PENDAHULUAN}

Latar Belakang. Pembangunan ekonomi daerah merupakan suatu proses kegiatan dimana pemerintah daerah beserta masyarakatnya mengelolah sumber daya dan potensi yang ada dan membentuk suatu pola kemitraan atau kerjasama antara pemerintah daerah dan sektor swasta untuk menciptakan berbagai lapangan pekerjaan baru, serta merangsang pertumbuhan dan perkembangan kegiatan ekonomi dalam daerah tersebut, 
Arsyad (2010).

Penelitian yang dilakukan oleh Setiawan dkk (2018) menyebutkan bahwa setiap daerah di Indonesia memiliki keunggulan ekonomi yang dapat menjadi sumber partumbuhan ekonomi. Kemampuan memacu pertumbuhan ekonomi suatu wilayah atau daerah sangat tergantung dari keunggulan atau daya saing sektor-sektor ekonomi di wilayahnya. Keunggulan atau daya saing suatu sektor ekonomi bukan saja menjadi alat pemacu pertumbuhan ekonomi yang positif, tetapi juga menjadi indikator penting sebagai penciptaan lapangan kerja baru dalam jangka panjang agar mampu menyerap tenaga kerja disuatu daerah.

Penelitian yang dilakukan oleh Katiandagho (2016) menyebutkan bahwa untuk mencapai keberhasilan pembangunan ekonomi daerah, maka suatu daerah harus mengetahui sektor apa saja yang menjadi sektor basis didaerah tersebut. Secara teoritis, meningkatnya sektor basis daerah akan meningkatkan penyerapan tenaga kerja dengan asumsi terjadi peningkatan investasi. Penelitian dari Syaiful dkk (2014) juga menyebutkan bahwa sampai saat ini pendekatan sektoral masih merupakan salah satu strategi dalam pembangunan daerah. Pendekatan sektor basis ini lebih menekankan pada pemilihan sektor-sektor ekonomi yang dapat lebih tepat dan cepat berperan sebagai penggerak ekonomi daerah, penyerap tenaga kerja dan pengentasan kemiskinan. Pendekatan sektoral lebih difokuskan kepada upaya peningkatan produktivitas sektor ekonomi melalui prioritas pembangunan dalam kebijakan daerah. Oleh karena itu, analisis tentang sektor yang menjadi basis/ keunggulan ekonomi di setiap wilayah menjadi sangat penting dilakukan sebagai pertimbangan dalam merumuskan kebijakan pembangunan. Dengan demikian akan diketahui sektor mana yang menjadi sektor basis dan paling besar peranannya dalam mendorong pertumbuhan ekonomi di kabupaten ini. Selain itu, keunggulan suatu sektor dapat pula dilihat dari indikator daya saingnya. Oleh karena itu daya saing sektor basis perlu pula dilihat, sehingga dapat diketahui ke depan sektor basis mana yang memiliki daya saing yang kuat sebagai sumber kekuatan ekonomi daerah.

Selain strategi peningkatan pembangunan melalui sektor basis, tenaga kerja juga merupakan bagian yang tidak dapat dipisahkan dalam suatu proses pembangunan. Faktor tenaga kerja tidak hanya dilihat sebagai satu bagian unit dalam penciptaan output, tetapi juga bagaimana kualitas tenaga kerja tersebut dapat berinteraksi dengan faktor-faktor produksi lainnya untuk menciptakan suatu nilai tambah (produktivitas) (Purwanti, 2009). Meningkatnya produktivitas tenaga kerja akan berdampak pada peningkatan nilai tambah yang dihasilkan. Selain pasar uang dan pasar barang, pasar tenaga kerja juga menentukan bekerjanya suatu sistem ekonomi dalam pembangunan.

Untuk meningkatkan tingkat kemandirian suatu daerah dan partisipasi masyarakat dalam pembangunan daerah maka pemerintah mengeluarkan kebijakan otonomi daerah melalui UU Nomor 23 tahun 2014 tentang Pemerintahan Daerah. Otonomi daerah merupakan kewenangan yang diberikan oleh pemerintah pusat kepada suatu daerah untuk mengatur dan mengurus kepentingan daerahnya sendiri berdasarkan aspirasi masyarakat sesuai dengan undang-undang yang berlaku.

Diberlakukannya otonomi daerah tersebut, pemerintah daerah harus lebih giat dan cerdas dalam menggali dan mengembangkan potensi daerahnya untuk meningkatkan perekonomian di daerah tersebut. 
Dengan kewenangan besar yang telah diberikan oleh pemerintah pusat kepada pemerintah daerah mewajibkan pemerintah daerah dan masyarakat secara bersamasama berpatisipasi dalam pembangunan daerah dengan memanfaatkan berbagai potensi daerah yang ada untuk mengetahui prioritas pembangunan daerah tersebut.

Kabupaten Gresik merupakan salah satu kabupaten di Provinsi Jawa Timur yang menyumbang proporsi PDRB tertinggi di Jawa Timur setelah Kota Surabaya,
Kabupaten Sidoarjo dan Kabupaten Pasuruan. Dengan distribusi persentase PDRB paling besar ada di Industri Pengolahan yaitu $47.9 \%$ pada tahun 2017, diharapkan mampu menjadi sektor yang meningkatkan perekonomian, Sementara itu, pertumbuhan ekonomi, tingkat pengangguran, jumlah angkatan kerja dan jumlah penduduk yang berkerja di Kabupaten Gresik dari tahun 2011 - 2017 mengalami fluktuasi seperti yang terlihat dalam tabel dibawah ini.

Tabel 1

Pertumbuhan ekonomi, Pengangguran Terbuka, di Kabupaten Gresik Tahun 2011 - 2017

\begin{tabular}{ccc}
\hline Tahun & $\begin{array}{c}\text { Pertumbuhan Ekonomi } \\
(\boldsymbol{\%})\end{array}$ & $\begin{array}{c}\text { Pengangguran } \\
(\boldsymbol{\%})\end{array}$ \\
\hline 2011 & 6.48 & 5.93 \\
2012 & 6.92 & 6.78 \\
2013 & 6.05 & 4.55 \\
2014 & 7.04 & 5.06 \\
2015 & 6.58 & 5.67 \\
2016 & 6.65 & 4.81 \\
2017 & 5.38 & 4.54 \\
\hline
\end{tabular}

Sumber : Kabupaten Gresik dalam Angka, 2018

Dari tabel diatas dapat diketahui bahwa pertumbuhan ekonomi di Kabupaten Gresik mengalami fluktuasi, begitu pula dengan tingkat pengangguran terbuka di Kabupaten Gresik. Pada tahun 2017, pertumbuhan ekonomi Kabupaten Gresik mengalami penurunan menjadi $5.38 \%$ dan penyerapan tenaga kerja di Kabupaten Gresik masih belum maksimal dengan tingkat pengangguran terbuka sebesar $4.54 \%$. Hal tersebut menandakan bahwa pertumbuhan ekonomi di Kabupaten Gresik tidak diiringi dengan kenaikan kesempatan kerja dan penurunan tingkat pengangguran terbuka. Tingginya angka pengangguran di Kabupaten Gresik menandakan bahwa sektor-sektor mata pencaharian yang tercermin dalam PDRB belum dimaksimalkan potensinya oleh Pemerintah Daerah Kabupaten Gresik.

Sesuai dengan latar belakang dan permasalahan yang dijelaskan di atas maka secara spesifik tujuan yang ingin dicapai dalam penelitian ini adalah untuk mengetahui sector-sektor yang menjadi basis dan non basis untuk dikembangkan sebagai penunjang pertumbuhan ekonomi di Kabupaten Gresik dan untuk mengetahui penyerapan tenaga kerja sektor basis dan non basis di Kabupaten Gresik.

\section{TINJAUAN TEORITIS}

Teori Basis Ekonomi. Dalam pembangunan daerah, salah satu teori ekonomi 
yang digunakan untuk meningkatan pembangunan ekonomi daerah adalah dengan teori basis ekonomi. Richardson menyatakan bahwa faktor penentu utama pertumbuhan ekonomi suatu daerah adalah berhubungan langsung dengan permintaan akan barang dan jasa dari luar daerah. Proses produksi di suatu daerah dengan sumber daya produksi lokal, termasuk tenaga kerja, dan bahan baku dan outputnya diekspor akan menghasilkan pertumbuhan ekonomi, peningkatan pendapatan per kapita dan penciptaan peluang kerja didaerah tersebut, Tambunan (2003).

Menurut Tarigan (2005), berdasarkan teori basis ekonomi, perkonomian suatu wilayah dibagi menjadi dua, yaitu sektor basis dan sektor non basis. Sektor basis adalah kegiatan-kegiatan yang mengekspor barang dan jasa ke luar batas - batas perkonomian wilayah yang bersangkutan. Sedangkan sektor non basis merupakan kegiatan-kegiatan yang menyediakan barang dan jasa untuk memenuhi kebutuhan orangorang yang bertempat tinggal di dalam batas-batas perkonomian wilayah tersebut.

Teori Ketenagakerjaan. UU Nomor 13 tahun 2003 yang mengatur tentang ketenagakerjaan menyebutkan bahwa tenaga kerja adalah setiap orang mampu melakukan pekerjaan guna menghasilkan barang dan atau jasa baik untuk memenuhi kebutuhan sendiri maupun masyarakat. Dalam pelaksanaan pembangunan nasional, tenaga kerja mempunyai peranan dan kedudukan yang sangat penting sebagai pelaku dan tujuan pembangunan.

Wiguna (2019) menjelaskan bahwa tenaga kerja merupakan salah satu faktor produksi dalam perekonomian, selain tanah, modal, dan kewirausahaan. Seseorang akan mulai bekerja apabila utility yang diterima lebih besar daripada utility tersebut menimbulkan penawaran tenaga kerja. Tenaga kerja adalah penduduk yang berumur di dalam batas usia kerja. Batasan usia kerja berbeda-beda antara negara satu dengan yang lain. Batas usia kerja yang dianut oleh Indonesia adalah minimum 15 tahun.

Dalam penelitian yang dilakukan oleh Darman dkk (2016) menyebutkan bahwa di Negara Sedang Berkembang, pertumbuhan lapangan kerja yang relatif lambat akan menyebabkan masalah pengangguran menjadi semakin serius. Setiawan dkk (2018) juga menjelaskan bahwa masalah ketenagakerjaan perlu mendapat perhatian dalam perencanaan pembangunan. Penyediaan kesempatan kerja yang luas sangat diperlukan untuk mengimbangi laju pertumbuhan penduduk usia muda yang masuk ke pasar tenaga kerja. Sempitnya lapangan kerja yang tersedia akan menyebabkan terjadinya pengangguran yang akan membawa masalah yang lebih besar lagi. Untuk mengurangi masalah ketenagakerjaan yang dihadapi Negara sedang berkembang perlu adanya solusi yaitu, memberikan upah yang memadai dan menyediakan kesempatankesempatan kerja kelompok orang miskin. Oleh karena itu, peningkatan kesempatan kerja merupakan unsur yang paling esensial dalam setiap strategi pembangunan yang menitikberatkan kepada penurunan pengangguran.

\section{METODE PENELITIAN}

Jenis Penelitian. Jenis penelitian ini termasuk dalam kategori penelitian kuantitatif, dikarenakan data yang digunakan dalam penelitian ini berupa angka-angka dan analisis statistik (Sugiyono, 2014). Tujuan dari penelitian ini yaitu untuk mengetahui dan menganalisis sektor basis dan non basis serta penyerapan tenaga kerja pada sektor tersebut. Maka dari itu peneliti menggunakan metode penelitian kuantitatif. 
Jenis dan Sumber Data. Data yang digunakan dalam penelitian ini adalah data sekunder dan data primer. Data sekunder adalah data penelitian yang diperoleh melalui media perantara atau secara tidak langsung yang berupa buku, catatan, bukti yang telah ada, atau arsip baik yang dipublikasikan maupun yang tidak dipublikasikan secara umum. Data primer adalah data yang dikumpulkan langsung oleh peneliti melalui sumbernya dengan melakukan penelitian ke objek yang diteliti. Data sekunder dalam penelitian ini terdiri dari data Produk Domestik Bruto menurut lapangan usaha Kabupaten Gresik dan Provinsi Jawa Timur serta data angkatan kerja Kabupaten Gresik dan Provinsi Jawa Timur. Data ini diperoleh dari Badan Pusat Statistika Provinsi Jawa Timur dan Badan Pusat Statistika Kabupaten Gresik serta penulis juga mencari data ke instansi terkait lainnya yang berhubungan dengan penelitian, berbagai literatur, internet dan sumbersumber lainnya. Data primer dalam penelitian ini berupa wawancara dengan aparat instansi terkait untuk menunjang kelengkapan data sekunder.

Metode Analisis Data. Untuk menjawab permasalahan yang sudah ditetapkan maka peneliti menggunakan metode analisis Location Quotient, Shiftshare dan Model Rasio Pertumbuhan untuk mengidentifikasi sektor basis dan non basis serta pertumbuhannya, kemudian peneliti juga mengidentifikasi penyerapan tenaga kerja sektor basis dan non basis di Kabupaten Gresik menggunakan analisis elastisitas tenaga kerja dan koefisien tenaga kerja.

\section{Analisis Location Quotient (LQ)}

Location Quotient atau disingkat LQ adalah suatu perbandingan tentang besarnya peranan suatu sektor atau industri di suatu daerah terhadap besarnya peranan sektor atau industri tersebut secara nasional
(Tarigan, 2004 dalam Katiandagho, 2017). Untuk menghitung rumus LQ digunakan rumus sebagai berikut:

$$
L Q_{i}=\frac{v_{i} / v_{t}}{V_{i} / V_{t}}
$$

LQi = Nilai LQ sub sektor i Kabupaten Gresik

$\mathrm{v}_{\mathrm{i}}=$ PDRB ADHK/Tenaga Kerja Sektor i Kabupaten Gresik

$\mathrm{v}_{\mathrm{t}}=$ PDRB ADHK/Tenaga Kerja Sektor i Provinsi Jawa Timur

$\mathrm{V}_{\mathrm{i}}=$ Total PDRB ADHK/Tenaga Kerja Kabupaten Gresik

$\mathrm{V}_{\mathrm{t}}=$ Total PDRB ADHK/Tenaga Kerja Provinsi Jawa Timur

Kriteria pengukuran model :

a. Jika nilai $L Q>1$, berarti sektor tersebut merupakan sektor basis, yang menunjukkan sektor tersebut mampu melayani pasar baik di dalam maupun di luar wilayah.

b. Jika nilai $L Q<1$, berarti sektor tersebut bukan merupakan sektor basis, yang menunjukkan suatu sektor belum mampu melayani pasar di wilayah.

\section{Analisis ShiftShare}

Analisis shift share juga digunakan untuk menganalisis pertumbuhan ekonomi suatu daerah sebagai perubahan atau peningkatan suatu indikator pertumbuhan perekonomian suatu wilayah dalam kurun waktu tertentu (Basuki, 2009). Adapun rumus dari RASS, PSS, DSS adalah sebagai berikut :

$$
\begin{aligned}
& R A S S=\frac{X^{\prime}}{X}-1 \\
& P S S_{j}=\frac{X^{{ }{ }_{j}}}{X_{. j}}-\frac{X_{.}{ }_{. j}}{X_{. .}} \\
& D S S_{i j}=\frac{X_{i j}^{\prime}}{X_{i j}}-\frac{X^{\prime}{ }_{j}}{X_{. j}}
\end{aligned}
$$

Keterangan :

Xij' = PDRB sektor i kabupaten/kota ke i di tahun akhir analisis 


$$
\begin{aligned}
\mathrm{Xij}= & \text { PDRB sektor } \mathrm{i} \text { kabupaten/kota ke } \mathrm{i} \\
& \text { tahun awal analisis }
\end{aligned}
$$

\section{Model Rasio Pertumbuhan}

Analisis Model Rasio Pertumbuhan digunakan untuk mengidentifikasi sektor ekonomi unggulan berdasarkan kriteria kontribusi nilai tambah maupun tenaga kerja. Model rasio pertumbuhan merupakan kegiatan membandingkan pertumbuhan suatu kegiatan baik dalam skala yang lebih kecil maupun dalam skala yang lebih luas. Untuk mendapatkan nilai rasio pertumbuhan digunakan rumus sebagai berikut :

a. Rasio Pertumbuhan Wilayah Studi (RPs)

$$
R P s=\frac{\Delta \mathrm{Xij} / \mathrm{X} 0 \mathrm{ij}}{\Delta X i n / X 0 \mathrm{in}}
$$

b. Rasio Pertumbuhan Wilayah Referensi (RPr)

$$
R P r=\frac{\Delta \mathrm{Xin} / \mathrm{X} 0 \mathrm{in}}{\Delta X n / X 0 n}
$$

Dimana :

$\Delta \mathrm{Xij}=$ Perubahan PDRB/Tenaga Kerja sektor i di Kabupaten Gresik

$\Delta \mathrm{Xin}=$ Perubahan $\mathrm{PDRB} /$ Tenaga Kerja sektor i di Provinsi Jawa Timur

$\Delta \mathrm{Xn}=$ Perubahan $\mathrm{PDRB} /$ Tenaga Kerja Provinsi Jawa Timur

$\mathrm{X} 0 \mathrm{ij}=\mathrm{PDRB} /$ Tenaga Kerja sektor $\mathrm{i}$ Kabupaten Gresik pada awal tahun

$\mathrm{Xij}=\mathrm{PDRB} /$ Tenaga Kerja sektor $\mathrm{i}$ Kabupaten Gresik pada akhir tahun

X0in $=$ PDRB/Tenaga Kerja sektor i Provinsi Jawa Timur pada awal tahun
$\mathrm{Xin}=\mathrm{PDRB} /$ Tenaga Kerja sektor $\mathrm{i}$ Provinsi Jawa Timur pada akhir tahun

$\mathrm{X} 0 \mathrm{n}=$ Total PDRB/Tenaga Kerja Provinsi Jawa Timur pada awal tahun

$\mathrm{Xn}=$ Total PDRB/Tenaga Kerja Provinsi Jawa Timur pada akhir tahun

\section{Elastisitas Tenaga Kerja}

Dalam menganalisis daya serap tenaga kerja masing-masing sektor, maka dilakukan hubungan antara pertumbuhan tenaga kerja dengan pertumbuhan Produk Domestik Regional Bruto yang dikenal dengan Elastisitas Tenaga Kerja yang dapat dirumuskan sebagai berikut (Simanjuntak, 1998 dalam Purwanti, 2009) :

$$
E=\frac{G n}{G y}
$$

Dimana :

$\mathrm{E} \quad=$ Elastisitas Tenaga Kerja

Gn $\quad=$ Pertumbuhan Tenaga Kerja

Gy = Pertumbuhan PDRB

\section{Analisis Koefisien Tenaga Kerja}

Analisis mengenai daya serap tenaga kerja juga dapat dilakukan dengan menghitung koefisien tenaga kerja. Koefisien tenaga kerja merupakan angka yang menunjukkan besarnya jumlah tenaga kerja yang diperlukan untuk menghasilkan satu unit nilai tambah dan dapat dirumuskan sebaga berikut :

$$
l i=\frac{L i}{X i}
$$

Dimana :

li $\quad=$ Koefisien Tenaga Kerja Sektor i

Li = Jumlah Tenaga Kerja Sektor i

$\mathrm{Xi}=$ Nilai Tambah Sektor $\mathrm{i}$

\section{HASIL DAN PEMBAHASAN}

Untuk mengetahui dan menganalisis sektor basis dan non basis beserta partumbuhannya di Kabupaten Gresik, maka digunakan 3 alat analisis, yaitu LQ (Locationt 
Quotient), analisis shift share (SS) serta analisis MRP. Hasil perhitungan ketiga alat analisis tersebut bisa dilihat pada tabel2.

Hasil perhitungan LQ menunjukkan sektor mana yang menjadi sektor basis yaitu apabila nilai LQ>1 dan non basis yaitu apabila nilai $L Q<1$. Tanda (+) dalam nilai PSS menunjukkan bahwa rata-rata daya tumbuh sektor tersebut lebih tinggi daripada daya tumbuh keseluruhan sektor di Provinsi
Jawa Timur. Kemudian tanda (+) dalam nilai DSS menunjukkan bahwa daya saing sektor tersebut lebih tinggi daripada daya saing keseluruhan sektor di Provinsi Jawa Timur. Tanda (+) dalam analisis MRP menunjukkan bahwa sektor tersebut memiliki pertumbuhan yang menonjol, baik di Kabupaten Gresik maupun Provinsi Jawa Timur.

Tabel 2

Matrik Data Hasil Penelitian Sektor Basis dan Non Basis beserta Pertumbuhannya

\begin{tabular}{|c|c|c|c|c|c|}
\hline \multirow{2}{*}{ Sektor } & \multirow{2}{*}{ LQ } & \multicolumn{2}{|c|}{ Shiftshare } & \multicolumn{2}{|c|}{ MRP } \\
\hline & & PSS & DSS & Gresik & Jatim \\
\hline Pertanian, Kehutanan, dan Perikanan & 0.57 & + & + & + & - \\
\hline Pertambangan dan Penggalian & 2.19 & - & - & - & - \\
\hline Industri Pengolahan & 1.64 & - & - & - & - \\
\hline Pengadaan Listrik dan Gas & 1.21 & - & + & + & - \\
\hline $\begin{array}{l}\text { Pengadaan Air, Pengelolaan Sampah, } \\
\text { Limbah dan Daur Ulang }\end{array}$ & 0.64 & - & + & + & - \\
\hline Konstruksi & 0.89 & + & + & + & + \\
\hline Perdagangan Besar dan Eceran & 0.66 & + & + & + & - \\
\hline Transportasi dan Pergudangan & 0.70 & + & - & - & + \\
\hline Penyediaan Akomodasi dan Makan Minum & 0.22 & + & + & + & + \\
\hline Informasi dan Komunikasi & 0.77 & + & + & + & - \\
\hline Jasa Keuangan dan Asuransi & 0.41 & + & - & - & + \\
\hline Real Estate & 0.72 & - & - & + & - \\
\hline Jasa Perusahaan & 0.34 & + & + & + & + \\
\hline $\begin{array}{l}\text { Administrasi Pemerintahan, Pertahanan } \\
\text { dan Jaminan Sosial Wajib }\end{array}$ & 0.51 & - & + & + & - \\
\hline Jasa Pendidikan & 0.31 & + & + & + & + \\
\hline Jasa Kesehatan dan Kegiatan Sosial & 0.58 & + & + & + & + \\
\hline Jasa lainnya & 0.20 & - & + & + & - \\
\hline
\end{tabular}

Sumber : PDRB Kab Gresik dan Prov Jatim, 2018

Hasil perhitungan dari rata-rata LQ menunjukkan bahwa sektor yang menjadi basis di Kabupaten Gresik adalah sektor pertambangan dan penggalian, sektor industri pengolahan dan sektor pengadaan listrik dan gas.
Sektor pertambangan dan penggalian dengan rata-rata nilai LQ sebesar 2,19 menjadi sektor basis karena Kabupaten Gresik memiliki sumberdaya alam migas seperti minyak, gas dan panas bumi, serta sember daya alam penggalian batu, pasir, tanah liat, batu kapur dan marmer. Hal 
tersebut dapat dilihat dari adanya tempat pengeboran minyak yang bertempat di perairan Ujung Pangkah Gresik. Pengeboran minyak ini dilakukan oleh PT. Hess Indonesia yang kemudian dikelola di Kawasan Industri Maspion. Kemudian hal ini berarti sektor pertambangan dan penggalian menjadi kegiatan ekonomi daerah yang mempunyai keunggulan komparatif untuk dikembangkan dalam mendorong proses pembangunan daerah di Kabupaten Gresik. Namun, karena sektor ini adalah komoditas sumberdaya alam yang tidak dapat diperbaharui maka kebijakan pengembangan untuk sektor pertambangan dan penggalian ini harus tetap berprinsip agar pengelolaannya dilakukan secara bijak dan berwawasan lingkungan, tidak hanya melakukan eksploitasi secara besar-besaran yang akan merugikan masyarakat. Perbaikan lingkungan setelah pembangunan harus dilakukan seperti reklamasi dan revegetasi lahan bekas tambang untuk mengurangi dampak buruk terhadap lingkungan.

Sektor industri pengolahan yang juga merupakan sektor basis di Kabupaten Gresik, dapat dipahami karena Kabupaten Gresik merupakan kabupaten dengan jumlah industri yang tinggi baik industri kecil dan menengah maupun industri besar yaitu sebanyak 408 industri di tahun 2017, hadirnya beberapa pusat kawasan industri di Kabupaten Gresik juga ikut mendorong hadirnya industry-industri lain secara aglomerasi. Industri pengolahan di Kabupaten Gresik ini didominasi oleh industri kimia, farmasi dan obat tradisional, industri makanan dan minuman, serta industri kayu, gabus dan barang anyaman bambu dan sejenisnya. Industri-industri tersebut missalnya PT. Petrokimia Gresik yang termasuk dalam Badan Usaha Milik Negara (BUMN) yang memproduksi pupuk pestisida dan industri bahan kimia. PT. Petrokimia Gresik merupakan produsen pupuk yang memasok $50 \%$ kebutuhan pupuk subsidi nasional (www.petrokimia-gresik.com), PT. Sumber Mas Indah Plywood, Perum Perhutani yang bergerak di bidang pengolahan kayu dan hasil Hutan. Industri-industri tersebut sebagian besar industri di Kabupaten Gresik ini berada di Kecamatan Kebomas dan Kecamatan Driyorejo.

Sektor pengadaan listrik dan gas yang juga merupakan sektor basis, dimana hal tersebut terkait dengan meningkatnya distribusi listrik yang berfungsi sebagai penunjang kegiatan perekonomian di Kabupaten Gresik.

Sedangkan sektor-sektor lainnya yang bukan merupakan sektor basis adalah sektor yang belum mampu melayani pasar di Kabupaten Gresik. Sektor non basis di Kabupaten Gresik adalah sektor pertanian, sektor pengadaan air, sektor konstruksi, sektor perdagangan, sektor transportasi, sektor penyediaan akomodasi, informasi dan komunikasi, sektor jasa keuangan, sektor real estate, sektor jasa perusahaan, sektor administrasi pemerintahan, ektor jasa pendidikan, sektor jasa kesehatan dan sektor jasa lainnya. Namun sektor non basis ini berfungsi sebagai penunjang dari sektor basis. Dengan demikian, keterpaduan anatara sektor basis dan non basis juga merupakan unsur penting dalam mendorong pertumbuhan ekonomi Kabupaten Gresik.

Hasil perhitungan shiftshare, yaitu nilai PSS dan DSS menunjukkan bahwa sektor yang rata-rata daya tumbuhnya lebih tinggi daripada daya tumbuh keseluruhan sektor di Provinsi Jawa Timur adalah sektor pertanian, penyediaan akomodasi makan minum, konstruksi, perdagangan, transportasi dan pergudangan, informasi dan komunikasi, jasa keuangan, jasa perusahaan, jasa pendidikan dan sektor jasa kesehatan, namun apabila dilihat dari nilai LQ, sektor-sektor 
tersebut merupakan sektor non basis, sedangkan sektor basis sendiri yaitu sektor pertambangan, industri pengolahan dan sektor pengadaan listrik dan gas memiliki daya tumbuh yang rendah dengan ditunjukkan tanda (-). Sedangkan sektor yang ratarata pertumbuhan daya saing lokalnya lebih tinggi daripada daya saing sektor yang sama di Provinsi Jawa Timur adalah sektor pertanian, pengadaan listrik, pengadaan air, konstruksi, perdagangan, informasi dan komunikasi, sektor penyediaan akomodasi makan dan minum, sektor jasa perusahaan, administrasi pemerintahan, jasa pendidikan, kesehatan serta sektor jasa lainnya, namun dari nilai LQ, sektor-sektor tersebut merupakan sektor non basis, hanya sektor pengadaan listrik yang sektor basis. Sehingga dapat dilihat bahwa daya tumbuh dan daya saing sektor non basis lebih tinggi daripada daya tumbuh sektor basis.

Analisis MRP menunjukkan bahwa sektor yang menonjol di Kabupaten Gresik maupun Provinsi Jawa Timur adalah sektor pengadaan listrik dan gas yang merupakan sektor basis dan sektor-sektor non basis yaitu sektor konstruksi, penyediaan akomodasi, sektor jasa perusahaan dan sektor jasa pendidikan.

Analisis penyerapan tenaga kerja pada sektor basis dan non basis di Kabupaten Gresik dapat dilihat dari nilai elastisitas dan koefisien tenaga kerja dalam tabel 3.

Hasil perhitungan rata-rata nilai elastisitas tenaga kerja menunjukkan bahwa seluruh sektor memiliki nilai elastisitas yang positif, hanya sektor pertanian yang memiliki nilai negatif. Hal tersebut berarti setiap kenaikan pertumbuhan ekonomi sebesar $1 \%$ pada sektor pertanian maka akan menurunkan jumlah tenaga kerja sektor tersebut. Kemudian sektor basis di Kabupaten Gresik yaitu sektor industri pengolahan yang memiliki nilai elastisitas yang rendah, yaitu hanya sebesar 0.078 yang berarti setiap kenaikan pertumbuhan ekonomi sektor industri pengolahan sebesar $1 \%$ maka akan meningkatkan tenaga kerja sebesar $0.078 \%$ dan hal tersebut berbeda dengan sektor basis yang lain, yang memi-

Tabel 3

Matrik Data Hasil Penelitian Penyerapan Tenaga Kerja di Kabupaten Gresik Tahun 2011 - 2017

\begin{tabular}{lcc}
\hline \multicolumn{1}{c}{ Sektor } & \multicolumn{2}{c}{ Penyerapan Tenaga Kerja } \\
\cline { 2 - 3 } & Elastisitas TK & Koefisien TK \\
\hline Pertanian, Perkebunan, Kehutanan, Perburuan, dan & -0.352 & 0.0136 \\
Perikanan & & \\
Pertambangan dan Penggalian & 6.669 & 0.0003 \\
Industri & 0.078 & 0.0041 \\
Listrik, Gas, dan Air Minum & 14.958 & 0.0058 \\
Konstruksi & 0.374 & 0.0053 \\
Perdagangan, Rumah Makan, dan Jasa Akomodasi & 0.782 & 0.0105 \\
Transportasi, Pergudangan, dan Komunikasi & 0.635 & 0.0044 \\
Lembaga Keuangan, Real Estate, Usaha Persewaan, & 2.024 & 0.0064 \\
dan Jasa Perusahaan & & \\
Jasa Kemasyarakatan, Sosial, dan Perorangan & 0.465 & 0.2910 \\
\hline
\end{tabular}

Sumber : Data PDRB dan Tenaga Kerja Kab Gresik dan Provinsi Jatim, 2018 


\section{Grafik 1}

\section{Elastisitas Tenaga Kerja Kabupaten Gresik Tahun 2011 - 2017}

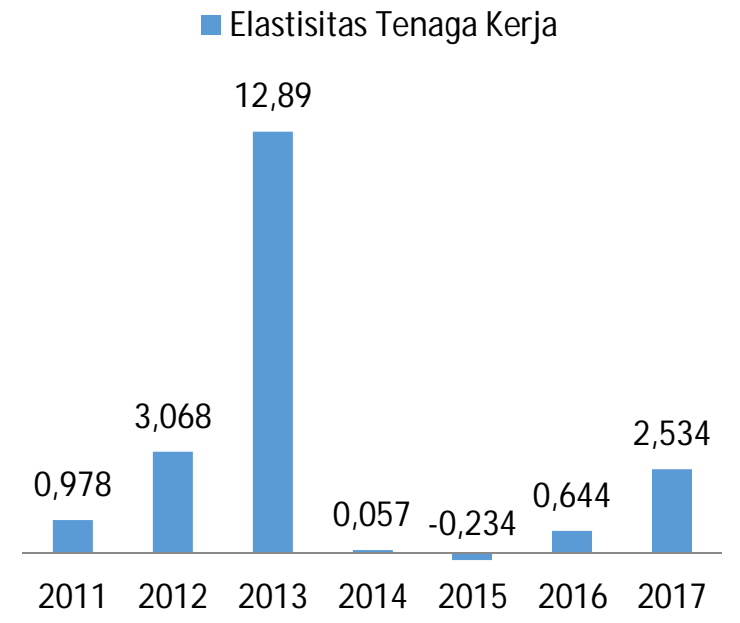

Sumber : PDRB dan Tenaga Kerja Gresik, 2018

liki rata-rata nilai elastisitas cukup tinggi. Sedangkan nilai elastisitas untuk sektor non basis tertinggi ada pada sektor lembaga keuangan dan sektor perdagangan. Kemudian secara keseluruhan, nilai elastisitas tenaga kerja di Kabupaten Gresik dapat dilihat pada grafik pada gambar 1.

Dari grafik diatas dapat diketahui bahwa nilai elastisitas tenaga kerja secara keseluruhan untuk Kabupaten Gresik pada tahun 2011 sebesar 0,978 yang berarti apabila kenaikan pertumbuhan ekonomi sebesar satu persen akan menyebabkan kenaikan partumbuhan tenaga kerja sebesar 0,978 persen. Kemudian pada tahun 2017 nilai elastisitas penyerapan tenaga kerja meningkat menjadi 2,534 yang berarti bahwa kenaikan pertumbuhan ekonomi sebesar satu persen mampu meningkatkan pertumbuhan tenaga kerja sebesar 2,534 persen. Kenaikan elastisitas ini mengindikasikan kemampuan partumbuhan ekonomi yang semakin meningkat dalam hal penyerapan tenaga kerja. Analisis ini digunakan untuk memperkirakan tambahan kesempatan kerja yang tercipta oleh lapangan perkerjaan yang ada akibat dari pertumbuhan ekonomi sebesar satu persen.

Tabel 3 menunjukkan rata-rata nilai koefisien tenaga kerja yang merupakan suatu angka yang menunjukkan besarnya jumlah tenaga kerja yang diperlukan untuk menghasilkan satu unit nilai tambah. Ratarata koefisien tenaga kerja menunjukkan hasil yang paling tinggi di sektor-sektor non basis, yaitu sektor tersier yang berupa sektor jasa kemasyarakatan, sektor perdagangan, sektor lembaga keuangan, kemudian di sektor primer, yaitu sektor pertanian. Rendahnya nilai koefisien tenaga kerja di sektor basis menunjukkan bahwa adanya indikasi bahwa sektor-sektor tersebut padat modal. Kemudian nilai koefisien tenaga kerja secara keseluruhan dapat dilihat pada grafik pada Gambar 2.

Kemudian dapat dilihat juga bahwa terjadi penurunan daya serap tenaga kerja secara total yang ditandai dengan penurunan koefisien tenaga kerja total dari 0,0498 pada tahun 2011 menjadi 0,0297 pada tahun 2017. Nilai ini menunjukkan bahwa pada tahun 2011 untuk menghasilkan nilai tambah 


\section{Grafik 2}

\section{Koefisien Tenaga Kerja Kabupaten Gresik Tahun 2011 - 2017}

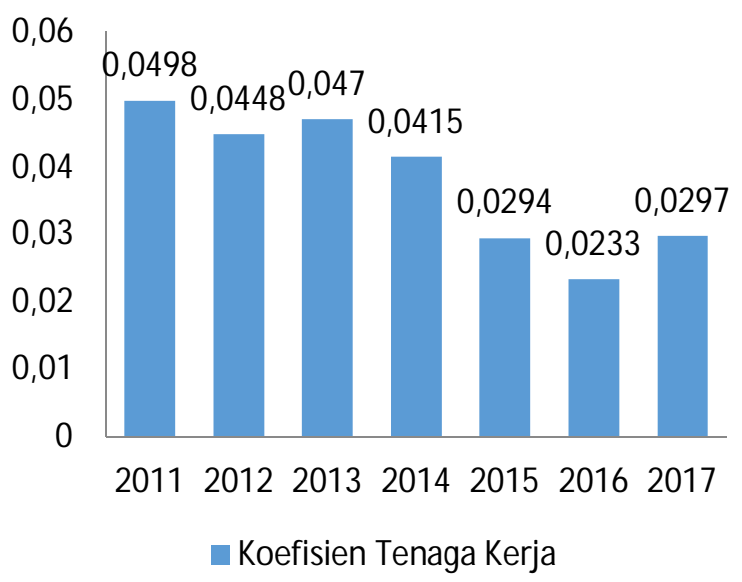

Sumber : Data PDRB dan Tenaga Kerja Kab Gresik, 2018

sebesar satu juta rupiah diperlukan 49,8 ribu tenaga kerja, sedangkan pada tahun 2017 hanya memerlukan 29,7 ribu tenaga kerja. Hal ini mengindikasikan adanya peningkatan produktivitas tenaga kerja.

\section{SIMPULAN}

Kesimpulan. Berdasarkan hasil pembahasan melalui berbagai alat analisis pada penelitian ini, maka dapat disimpulkan bahwa:

1. Analisis Sektor Unggulan di Kabupaten Gresik :

a. Secara keseluruhan, sektor ekonomi yang menjadi basis berdasarkan kontribusi dilihat dari sisi penciptaan nilai tambah adalah sektor pertambangan dan penggalian, sektor industri pengolahan dan sektor pengadaan listrik dan gas.

b. Analisis shiftshare pada periode 20112017 menunjukkan bahwa di Kabupaten Gresik, sektor yang rata-rata daya tumbuhnya lebih tinggi daripada pertumbuhan ekonomi secara keseluruhan dalam periode yang sama adalah sektor pertanian, penyediaan akomo- dasi makan minum, konstruksi, perdagangan, transportasi dan pergudangan, informasi dan komunikasi, jasa keuangan, jasa perusahaan, jasa pendidikan dan sektor jasa kesehatan. Sedangkan sektor yang rata-rata pertumbuhan daya saing lokalnya lebih tinggi daripada daya saing sektor yang sama di Provinsi Jawa Timur adalah sektor pertanian, pengadaan listrik, pengadaan air, konstruksi, perdagangan, informasi dan komunikasi, sektor penyediaan akomodasi makan dan minum, sektor jasa perusahaan, administrasi pemerintahan, jasa pendidikan, kesehatan dan sektor jasa lainnya.

c. Analisis Model Rasio Pertumbuhan (MRP) periode 2011-2017 menunjukkan sektor yang sisi pertumbuhannya dominan baik di Provinsi Jawa Timur maupun Kabupaten Gresik adalah sektor kontruksi, sektor penyediaan akomodasi makan minum, sektor jasa perusahaan, sektor jasa pendidikan dan jasa kesehatan.

2. Analisis Penyerapan Tenaga Kerja di Sektor Basis dan Non Basis : 
a. Rata-rata nilai elastisitas tenaga kerja di Kabupaten Gresik menunjukkan bahwa seluruh sektor memiliki nilai elastisitas yang positif, hanya sektor pertanian yang memiliki nilai negatif. Hal tersebut berarti setiap kenaikan pertumbuhan ekonomi sebesar $1 \%$ pada sektor pertanian maka akan menurunkan jumlah tenaga kerja sektor tersebut. Kemudian sektor basis di Kabupaten Gresik yaitu sektor industri pengolahan yang memiliki nilai elastisitas yang rendah, yaitu hanya sebesar 0.078 yang berarti setiap kenaikan pertumbuhan ekonomi sektor industri pengolahan sebesar $1 \%$ maka akan meningkatkan tenaga kerja sebesar $0.078 \%$ dan hal tersebut berbeda dengan sektor basis yang lain, yang memiliki rata-rata nilai elastisitas cukup tinggi. Sedangkan nilai elastisitas untuk sektor non basis tertinggi ada pada sektor lembaga keuangan dan sektor perdagangan. Pada periode 2011-2017, nilai elastisitas tenaga kerja di Kabupaten Gresik mengalami fluktuasi. Pada tahun 2011 sebesar 0,978 yang berarti apabila kenaikan pertumbuhan ekonomi sebesar satu persen akan menyebabkan kenaikan pertumbuhan tenaga kerja sebesar 0,978 persen. Kemudian pada tahun 2017 nilai elastisitas penyerapan tenaga kerja meningkat menjadi 2,534 yang berarti bahwa kenaikan partumbuhan ekonomi sebesar satu persen mampu meningkatkan pertumbuhan tenaga kerja sebesar 2,534 persen. Kenaikan elastisitas ini mengindikasikan kemampuan pertumbuhan ekonomi yang semakin meningkat dalam hal penyerapan tenaga kerja.

b. Dari hasil analisis koefisien tenaga kerja, rata-rata nilai koefisien tertinggi ada pada sektor non basis, yaitu sektor administrasi pemerintahan, sektor jasa pendidikan, sektor jasa kesehatan, sektor jasa lainnya. Kemudian dapat diketahui terjadi penurunan koefisien tenaga kerja dari tahun 2011 - 2017, yang mengindikasikan adanya peningkatan produktivitas tenaga kerja. Penurunan ini mengindikasikan adanya tahapan kemajuan perekonomian suatu daerah dari tradisional menuju industri. Namun di sisi lain, penurunan ini berdampak tidak baik dalam hal penyerapan tenaga kerja karena mengakibatkan pengangguran yang semakin tinggi.

\section{DAFTAR PUSTAKA}

Arsyad, Lincolin, 2004. Ekonomi Pembangunan. Yogyakarta: STIE YKPN.

Baransano, M. A., Putri, E. I. K., Achsani, N. A., \& Kolopaking, L. 2016. Peranan Sektor Unggulan sebagai Salah Satu Faktor dalam Mengurangi Ketimpangan Pembangunan Wilayah di Provinsi Papua Barat. Jurnal Perencanaan Wilayah Dan Kota, 27(2), 119.

Badan Pusat Statistika. Kabupaten Gresik dalam Angka 2011 - 2018.

Darman, \& Afiat, M. N. 2016. Analisis Sektor Unggulan Dan Penyerapan Tenaga Kerja Di

Provinsi Sulawesi Tenggara. Jurnal Ekonomi, 1(April)

Katiandagho, O., Kapantouw, G. H. M., \& Pakasi, C. B. D. 2017. Peran Sektor Basis Dalam Penyerapan Tenaga Kerja Di Provinsi Sulawesi Utara. Jurnal Agri - Sosio Ekonomi, 13

Kuncoro, Mudrajat. 2004. Otonomi dan Pembangunan Daerah. Surabaya. Erlangga

Kurniawan, A. W., \& Bado, B. 2017. Potensi Sektoral Dan Dampaknya Terhadap Penyerapan Tenaga Kerja Di Kota Makassar. Jurnal Ekonomi, 5(2), 203-214. Maslowan, I. 2017. Analisis Sektor Basis Dan 
Non Basis Ekonomi Kota Tomohon Tahun 2011 - 2015. Jurnal Berkala Ilmiah Efisiensi, 17(02), 782-792.

Sadono Soekirno. 1994. Pengantar Teori Makro Ekonomi. Jakarta: PT Raja Grafindo Persada

Santoso, M. F. 2015. Identifikasi Potensi Sektor

Ekonomi Basis Dan Non Basis Kota Kediri Tahun 2009 - 2013. Jurnal Ekonomi, 3.

Setiawan, D., Prihanto, P. H., \& Mustika, C.

(2018). Analisis Hubungan Sektor Ekonomi Basis Dengan Penyerapan Tenaga Kerja Di Kabupaten Merangin. Jurnal Ekonomi Sumberdaya Dan Lingkungan, 7(1), 23-32 Syaiful, Syaparuddin, \& Artis, D. 2014. Analisis
Sektor Basis dalam Hubungannya dengan Penyerapan Tenaga Kerja Di Kabupaten Batang Hari. Jurnal Perspektif Pembiayaan Dan Pembangunan Daerah

Tambunan, T.H Tulus. 2003. Perekonomian Indonesia Beberapa Masalah Penting. Jakarta: Ghalia Indonesia

Tarigan, R. 2005. Perencanaan Pembangunan Wilayah. Edisi Revisi. Jakarta: Bumi Aksara.

Todaro, Michael P. dan Smith, Stephen C. 2006. Pembangunan Ekonomi Edisi Kesembilan. Munandar, Haris [penerjemah]. Jakarta: Erlangga 